\title{
KOBLEN PRISON MUSEUM AS AN EMBODIMENT OF HISTORICAL INTERPRETATION NARRATIVES BASED ON PEIRCEAN SIGN SYSTEM IN SURABAYA
}

\author{
Arda Cahyo Pranowo, Hari Purnomo, Josef Prijotomo \\ Department of Architecture, Institut Teknologi Sepuluh Nopember, Indonesia \\ e-mail: arda.pranowo@gmail.com
}

\begin{abstract}
Historical interpretation on the site of cultural heritage as a series of signs could be used as a channel for creativity in architectural design. History was a subjective interpretation from personal view that had been documented or published to the public. This thesis is looking for the narratives that had been presented within former Koblen Prison as a specific case study so it could be used to produce design criterias for the new facilities. The brief research process was involving document findings, site exploration, and evidence gathering. After all related evidences have been collected, the next activity was a critical analysis of the story with logical argumentation. Categorization should be done to simplify the complexities that arise so that it can be applied appropriately to the architectural expression. Each category was then studied based on signs according to Peirce's trichotomy so that may explain the relation of meaning that emerged from the the observer's point of view. Peirce's approach was in a semiotics discourse that had different scope from architecture discourses but it would be useful for understanding the meaning and their connections. The stories that appear on the site consists of three main stories. The stories include the story of the struggle for independence, the story of prison life, and the story of architectural transition. Museum was the new facility that was expected to be the solution to the problem of abandoned cultural heritage sites in the former Koblen Prison in Surabaya. The main result of the research was a museum design study that communicates with the observer about the site's pasts and respects the site's contexts through architectural expressions.
\end{abstract}

Keywords: museum, Koblen prison, semiotics, Peircean sign system

\begin{abstract}
ABSTRAK
Interpretasi historis pada sebuah situs kebudayaan sebagai kumpulan penanda dapat digunakan sebagai saluran kreativitas dalam desain arsitektur. Sejarah merupakan interpretasi subjektif dari sudut pandang personal yang telah didokumentasikan atau dipublikasikan ke publik. Tesis ini mencari kisah-kisah yang
\end{abstract}


telah ada tentang eks penjara koblen sebagai sebuah studi kasus spesifik yang dapat digunakan untuk memproduksi kriteria-kriteria desain untuk fasilitas-fasilitas baru. Proses penelitian yang singkat melibatkan penemuan dokumen, eksplorasi situs dan pengumpulan bukti. Setelah semua bukti terkait sudah dikumpulkan, selanjutnya adalah analisis kritis terhadap kisah dengan argumentasi logis. Kategorisasi dilakukan untuk mempermudah kompleksitas yang timbul sehingga dapat di terapkan secara tepat ke ekspresi arsitektur. Masing-masking kategori kemudian dipelajari berdasarkan pertanda menurut tiga pembagian Peircean, sehingga dapat menjelaskan hubungan makna yang timbul dari sudut pandang pengamat. Pende-katan Peircean menggunakan wacana semiotic yang memiliki perbedaan ruang lingkup dari wacana arsitektur tetapi bermanfaat untuk memahami makna dan hubunganhubungan mereka. Kisah-kisah yang muncul di situs berisi tiga kisah utama. Kisah yang termasuk kisah perjuangan kemerdekaan, kisah kehidupan penjara dan kisah mengenai transisi arsitektur. Museum adalah fasilitas baru yang diharapkan menjadi solusi atas masalah terbengkalainya situs kebudayaan di eks penjara koblen di Surabaya. Hasil utama penelitian adalah studi desain museum yang berkomunikasi dengan pengamat mengenai masa lalu situs dan menghormati konteks situs melalui ekspresi arsitektur.

Kata kunci: museum, penjara Koblen, semiotic, sistem pertanda Peircean

\section{INTRODUCTION}

Architecture as communication was the main issue of this study. Stories contained within the cultural heritage site could be communicated to interpreters by architecture as media. Historical interpretatives research as method for gaining narratives that explaining something that presented in the past. Redevelopment of the abandoned cultural heritage site was using conservation method in preserving old buildings and other remaining ruins could be found.

This study was looking for methods on emerging the past memories into museum according to contemporary contexts in the site of cultural heritage. How the remains from the past could be important parts of the new facilities design? How the narratives from historical interpretation about the site could be conveyed to the public by architecural design?

Historical interpretatives was used for finding the stories contained in a cultural heritage site. Multiple stories with multiple subjects could be retrieved from that methods. Evidences were collected, organized, and analyzed so it could be useful for creating design criterias required for the design. Those stories then categorized by subject of the stories condition so it would be simpler and more thorough to be translated into architecture. These categories can be understood as the messages will delivered by designers to the observers. These categories were a sequence of subject's conditions chronologically. 
Categories were then examined with an approach based on Peirce's tricotomy, which include index, icon, and symbol. This process was involving descriptive and logical argumentation approaches to examine indexes, icons, and symbols emerged from the categories so could be underst. System of sign includes 'signified', 'signifier', and 'actual function'.

Presenting memories from the past into architecture that fulfill the contemporary requirements in the cultural heritage site was the main important thing in this discussion. So there was a way to communicate the historical intepretation narratives that could be retrieved from Koblen Prison. And because the site was a cultural heritage, the reuse of remaining building of old Koblen Prison as design elements in the built environment also to be considered.

\section{Materials and Methods}

Charles Peirce introduced triadic model for understanding something around us in the universe besides monad and dyad models [Dougherty, 1990]. In tryadic model, there was third component that was influencing the meaning of something. So if it has been used in architectural discourse, there was three elements for creating meaning and intepretation, that are designer intention, building, and interpreter. This triadic model was a better approaches for understanding meaning of an object. Peirce argued that the sign is defined 'in terms of a triadic process, called semiosis, are not a class of objects and exist only in the mind of the interpreter' (Nöth,1990).

Table 1. Relation between Peirce Trichotomy and Type of Design Based on Broadbent (1980)

\begin{tabular}{lllll}
\hline $\begin{array}{l}\text { No. } \\
\text { Peircean } \\
\text { Trichotomy }\end{array}$ & Type of Design & Interpreter Responds & $\begin{array}{l}\text { Correlation } \\
\text { with } \\
\text { Contents and } \\
\text { Expression }\end{array}$ \\
\hline $1 \quad$ Icon & $\begin{array}{l}\text { Canonic; } \\
\text { Analogic }\end{array}$ & $\begin{array}{l}\text { - Physical Causal activity } \\
\text { - Logical-mathematical } \\
\text { structure } \\
\text { Direct Physiological Responds }\end{array}$ & $\begin{array}{l}\text { Similarity } \\
\text { 'tend to be' } \\
\text { Pragmatic }\end{array}$ & $\begin{array}{l}\text { Physical } \\
\text { Connection }\end{array}$ \\
& Index & 'tend to be' & $\begin{array}{l}\text { De Jure; } \\
\text { Respon tergantung adat, } \\
\text { budaya dan yang telah } \\
\text { dipelajari. }\end{array}$ & $\begin{array}{l}\text { Indirect } \\
\text { association }\end{array}$ \\
\hline
\end{tabular}

Architecture is the use of formal of signifier which can includes material and surface for articulating the 'signified' that could be the way of life, values, and function, 
with a certain way (structural, economical, technical, and mechanical) [Jenks, 1980]. Signs in architecture could be understood as expressions and contents according to Hjelmslev [Jenks, 1980]. Jenks make the 'signified' equals to 'content' and the 'signifier' equals to 'expression'. The relation of content and expression considered There are four ways of design according to Geoffrey Broadbent that could be used as the method for creating architectures. These ways are pragmatic design, analogic design, typologic design, and canonic design. These four ways in design can be used to resolve the case based on the concepts have been made. Design criterias produced based on the trichotomy were then can be used as guidelines for creating design concepts.

\section{Study Area Descriptions}

Location for the design is in the site of former Koblen Prison in Jalan Koblen Kidul. Site didn't have any specific function according City Planning (Surabaya City Government, 2003) and has been used as market. Total area of the site is 3 hectares. There were remaining old Prison's walls that surrounding the site and some watchtowers.

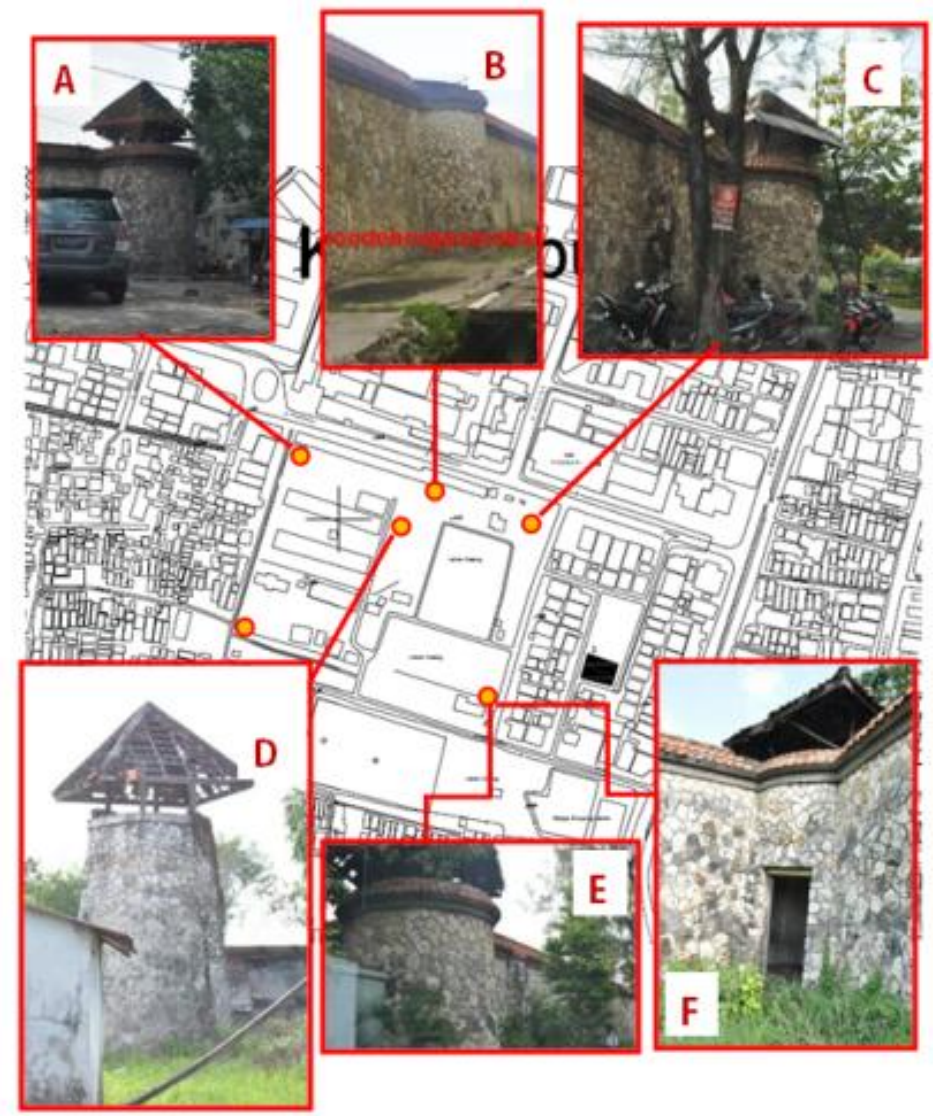

Figure 1. Remaining Watchtowers of Koblen Prison 


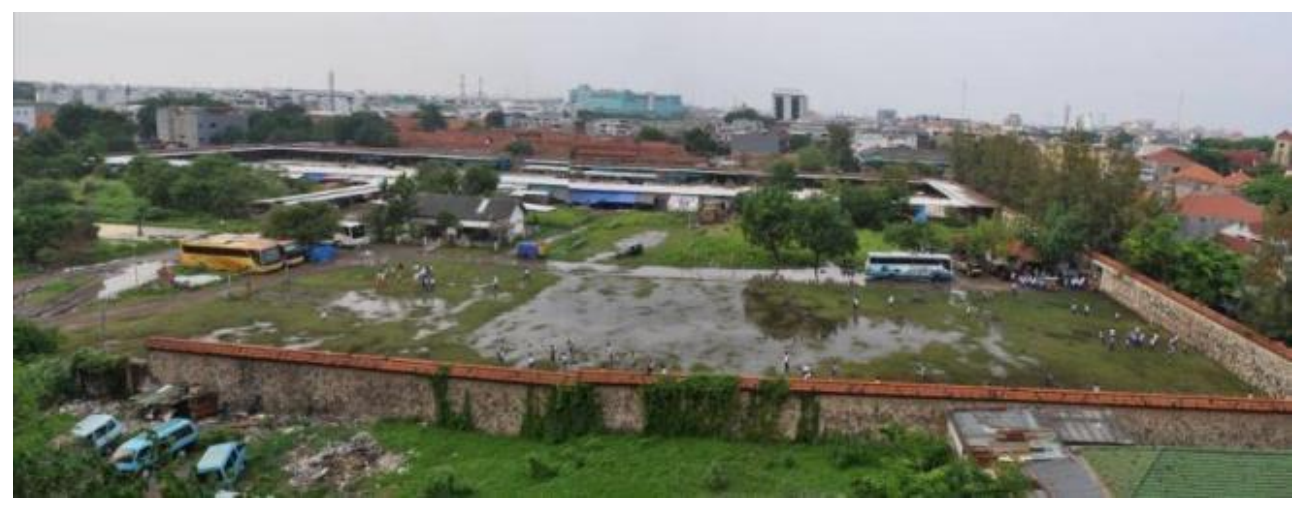

Figure 2. Koblen Prison View from BG Junction Parking Building at the South

\section{Collection of data}

Evidence collected in the research includes published or unpublished documents, newspapers, correspondences, diaries, photographs, artifacts, and buildings that were connected to the Koblen Prison. These evidences could be connected either directly or indirectly.

\section{The Analysis}

Collected materials were organized and compiled according to time of events and contexts. Narrations or Stories were produced by this process. There are three narratives that correspond the site's past. They are:

1. The story of the struggle for independence

2. The story of prison life

3. The story of architectural transition

These three main narratives were then to be categorized by the subject's conditions involved in the stories. The categories were sequencial signs that arranged according to times. As Jenks writings about Semiotics (Jenks, 1980), architecture was a sign system based on Hjelmslev's thoughts that includes the contents and the expressions. The contents and expressions were also considered as signified and signifier.

Peircean trichotomy (Dougherty, 1990), including index, icon, and symbol, was used for understanding the categories. These approaches were taken for covering different kind of connection between architecture and its messages, that would be understood as connection between architectural expressions and its contents. The expressions could be. 


\section{Design Concepts According to the Analysis of the Peircean Sign System on the Narratives}

1. The story of struggle for independence

The narratives were categorized by the subjects conditions across the time. The subject was Common People of Indonesia's Archipelago. Those categories are Colonized - Realized - In Battle - Independence - Defending - Creating.

Table 2. Design Concepts based on Architectural Expressions Form by the Story of Struggle for Independence

\begin{tabular}{|c|c|c|c|}
\hline No. & Phase & Parameter & Design Concept \\
\hline \multirow[t]{3}{*}{$\mathrm{a}$} & Colonized & Form & $\begin{array}{l}\text { Small space with dark condition; Form of the inside } \\
\text { similar to the prison corridors including the cells; } \\
\text { Building form influenced by the Dutch Colonial style; } \\
\text { At the specific part, building mass was a rigid box } \\
\text { with narrow elongated openings. }\end{array}$ \\
\hline & & Space & $\begin{array}{l}\text { Small space in the dark condition; there were spaces } \\
\text { that cannot be entered; Spaces that were confusing the } \\
\text { visitors; there was space for farming in the exterior } \\
\text { illustrating the era of cultuurselsel. }\end{array}$ \\
\hline & & Surface & $\begin{array}{l}\text { Dull plastered textures; The specific part was dark } \\
\text { surface and lightened by minimal artificial lightings. }\end{array}$ \\
\hline \multirow[t]{3}{*}{$\mathrm{b}$} & Realized & Form & $\begin{array}{l}\text { - The size of the room is wider than the previous stage } \\
\text { - The mass of the building is no longer using the } \\
\text { default style of the Dutch building } \\
\text { - The structure of the building which used a new } \\
\text { approach but is still not settled and arranged } \\
\text { appropriately. }\end{array}$ \\
\hline & & Space & $\begin{array}{l}\text { - Space is elongated and wider than before } \\
\text { - Allow space to be able to see the previous position or } \\
\text { a position that will be passed by the visitors. }\end{array}$ \\
\hline & & Surface & $\begin{array}{l}\text { - Surface casing has openings that allow the observer } \\
\text { to see the previous position and that will be passed } \\
\text { - There is an opening that allows observers to see } \\
\text { farming activities as a depiction of the condition of } \\
\text { colonized community. }\end{array}$ \\
\hline $\mathrm{c}$ & In Battle & Form & $\begin{array}{l}\text { - Establish an increasingly uphill stepping up so } \\
\text { harder to be passed by the visitors } \\
\text { - In the initial stage made of wooden wall depicting } \\
\text { the use of material with a local approach } \\
\text { - At the next stage of the explosion broke the wall of a } \\
\text { literal that describes the process of damage in battle. }\end{array}$ \\
\hline
\end{tabular}




\begin{tabular}{|c|c|c|c|}
\hline No. & Phase & Parameter & Design Concept \\
\hline \multirow{5}{*}{$\mathrm{d}$} & & Space & $\begin{array}{l}\text { - Space is the other end of the elongated hall has a } \\
\text { higher position } \\
\text { - Conditions have uneven lighting for depicting the } \\
\text { emergency of war condition. }\end{array}$ \\
\hline & & Surface & $\begin{array}{l}\text { There are a few ornaments of gun shells and traces of } \\
\text { old blood spills on the surface. }\end{array}$ \\
\hline & Independence & Form & $\begin{array}{l}\text { The most open building, where the surface is the most } \\
\text { extensive openings. }\end{array}$ \\
\hline & & Space & $\begin{array}{l}\text { There is a bifurcation of the paths so that the } \\
\text { circulation of visitors are free to continue the journey } \\
\text { of the galleries or to other places such as the } \\
\text { performance space or plaza. }\end{array}$ \\
\hline & & Surface & $\begin{array}{l}\text { Surface casing space was already the most open } \\
\text { conditions due to rupture. This condition allows } \\
\text { visitors to experience the real scene of outside, the } \\
\text { outside air and the outside light. }\end{array}$ \\
\hline \multirow[t]{3}{*}{ e } & Defending & Form & $\begin{array}{l}\text { - Notching paths that is sloping down again after a } \\
\text { higher position } \\
\text { - The surface was enclosed back } \\
\text { - stuck on the end so it must turn to illustrate the } \\
\text { difficulty of the struggle for independence }\end{array}$ \\
\hline & & Space & The room that has irregular lighting \\
\hline & & Surface & $\begin{array}{l}\text { There will be trail ornamentation bloodshed and gun } \\
\text { shells. }\end{array}$ \\
\hline \multirow[t]{3}{*}{$f$} & Creating & Form & $\begin{array}{l}\text { - The elongated mass higher and higher } \\
\text { - Have a maximum lighting } \\
\text { The use of architecture that is identical to the locality }\end{array}$ \\
\hline & & Space & $\begin{array}{l}\text { - Elongated Space used as art exhibitions and } \\
\text { innovation. } \\
\text { - At the end of the trip is used as an exhibition of } \\
\text { artworks or installations which are changed } \\
\text { periodically. }\end{array}$ \\
\hline & & Surface & $\begin{array}{l}\text { - changing roof materials with intention of changing } \\
\text { the functional experiments. Material used is clay tile } \\
\text { roof, aluminum composite panel roofing, solar roof } \\
\text { panels, and the roof of living plants } \\
\text { - The character of neutral surface with white color so } \\
\text { the artwork on display becomes focus of attention. }\end{array}$ \\
\hline
\end{tabular}


2. The story of prison life

The narratives were categorized by the subjects conditions across the time. The subject was a prisoner. Those categories are Isolated - Falling - Disoriented Enlightened - Freedom.

Table 3. Design Concepts Based on Architectural Expressions Form by the Story of Prison Life

\begin{tabular}{|c|c|c|c|}
\hline No. & Phase & Parameter & Design Concept \\
\hline \multirow[t]{3}{*}{$\mathrm{g}$} & Isolated & Form & $\begin{array}{l}\text { - The fence wire or high iron railings. } \\
\text { - The fence on the existing walls of the Cretaceous as } \\
\text { high. So can not see around anymore. } \\
\text { - There are several openings viusal that allows people } \\
\text { from a wider place to see and vice versa. }\end{array}$ \\
\hline & & Space & $\begin{array}{l}\text { Space limited, but still could see outside the } \\
\text { boundaries } \\
\text { - Space is limited both motion and visual } \\
\text { - The existence of supervision by people who are more } \\
\text { free (located in the larger space) }\end{array}$ \\
\hline & & Surface & $\begin{array}{l}\text { - Material of steel wire on the fence wire } \\
\text { - Materials such as limestone on the walls of the } \\
\text { existing fence }\end{array}$ \\
\hline \multirow[t]{3}{*}{$\mathrm{h}$} & Falling & Form & $\begin{array}{l}\text { The size of a room divider and a narrow elongated } \\
\text { horizontally and vertically } \\
\text { - The loop shape of the cell on either side of the hall } \\
\text { - At the beginning of the lighting and the sound is still } \\
\text { possible to enter from outside. } \\
\text { - The more into the natural lighting and noise from } \\
\text { outside can not enter }\end{array}$ \\
\hline & & Space & $\begin{array}{l}\text { the long, dark corridor narrows down to the size of a } \\
\text { human right } \\
\text { - The loop space of cells that can not be entered on the } \\
\text { side }\end{array}$ \\
\hline & & Surface & $\begin{array}{l}\text { - The end of the hallway that can not be expected } \\
\text { eventually. }\end{array}$ \\
\hline \multirow[t]{3}{*}{$\mathrm{i}$} & Disoriented & Form & $\begin{array}{l}\text { Steel bars in each cell is textured rust. } \\
\text { - The walls of the grim look of weathered material }\end{array}$ \\
\hline & & Space & $\begin{array}{l}\text { - The corridor is narrow and many branches } \\
\text { - Has some light and narrow openings as directions } \\
\text { and ventilations }\end{array}$ \\
\hline & & Surface & $\begin{array}{l}\text { Space is a long winding hallway, branched like a } \\
\text { labyrinth }\end{array}$ \\
\hline
\end{tabular}




\begin{tabular}{|c|c|c|c|}
\hline No. & Phase & Parameter & Design Concept \\
\hline \multirow[t]{4}{*}{$\mathrm{j}$} & Enlightened & Form & $\begin{array}{l}\text { Using the same wall material with the existing fence } \\
\text { wall }\end{array}$ \\
\hline & & Space & The room began opening more \\
\hline & & & $\begin{array}{l}\text { - The space is more extensive than previously } \\
\text { - Room arranged lengthwise so that the end was seen } \\
\text { by visitors } \\
\text { - The position of the space makes it possible to view } \\
\text { previous position and the position of the next. }\end{array}$ \\
\hline & & Surface & $\begin{array}{l}\text { - There is an illuminating light of the head of visitors } \\
\text { - There are openings that can look around, including } \\
\text { the position that has passed and the next position. } \\
\text { - There were art workw of other people because at this } \\
\text { stage a more appreciative of their surroundings. }\end{array}$ \\
\hline \multirow[t]{3}{*}{$\mathrm{k}$} & Freedom & Form & Establish a more open space than the previous \\
\hline & & Space & $\begin{array}{l}\text { - The size of a large space and elongated with brighter } \\
\text { lighting. } \\
\text { - Outstanding visual barrier-free space that allows for a } \\
\text { good look around, sample the top position with } \\
\text { openings on all sides. }\end{array}$ \\
\hline & & Surface & $\begin{array}{l}\text { - The color of the bright surface of the sheath } \\
\text { - There are more openings } \\
\text { - There is the succession of works of art on display }\end{array}$ \\
\hline
\end{tabular}

3. The story of architectural transition

The narratives were categorized by the subjects conditions across the time. The subject was architecture style. Those categories are Dutch Colonialization Architecture - Javanesse Architecture

Table 4. Design Concepts based on Architectural Expressions Form by the Story of Architectural Transition

\begin{tabular}{|c|c|c|c|}
\hline No. & Phase & Parameter & Design Concept \\
\hline \multirow[t]{2}{*}{1} & $\begin{array}{l}\text { The Dutch } \\
\text { Colonial } \\
\text { Architecture } \\
\text { Javanesse }\end{array}$ & Form & $\begin{array}{l}\text { - Gavels dominated the facades } \\
\text { - There is a tower at the entrance } \\
\text { - The interior provide details that follow approach the } \\
\text { essence of the art and craft by PJH Cuypers. }\end{array}$ \\
\hline & & Space & $\begin{array}{l}\text { - galleries around the building to avoid direct sunlight } \\
\text { and rain water pourings. } \\
\text { - The orientation of the building trying to avoid the }\end{array}$ \\
\hline
\end{tabular}




\begin{tabular}{|c|c|c|c|}
\hline No. & Phase & Parameter & Design Concept \\
\hline & & & $\begin{array}{l}\text { East and West } \\
\text { - Establish a lean massing of the building }\end{array}$ \\
\hline & & Surface & $\begin{array}{l}\text { - There is a wide vents to allow cross-ventilation as } \\
\text { possible. } \\
\text { - Sometimes take the decorations that are applied to } \\
\text { the local details of the building. (example: HVA in } \\
\text { Jalan Merak) }\end{array}$ \\
\hline \multirow[t]{2}{*}{$\mathrm{m}$} & Architecture & Form & $\begin{array}{l}\text { - The form is taken directly from the Java architecture } \\
\text { that can be understood is the shape of the roof. The use } \\
\text { of form and figure of the roof on Java architecture is a } \\
\text { strong character that attaches to the local architecture } \\
\text { of Java. } \\
\text { - The village roofs on buildings around the gallery. } \\
\text { - The roof on the building joglo middle. } \\
\text { - Blandar and sleigh as forming a major component of } \\
\text { Java architecture. } \\
\text { - The roof of the main building function joglo on the } \\
\text { main art gallery and performance space that is a place } \\
\text { that has the highest hierarchy in the zoning. } \\
\text { - The roof of the village on the function of surrounding } \\
\text { buildings. } \\
\text { - Use the Teacher sector assemblies and beam-forming } \\
\text { sledge as a symbol of architectural space that Java is } \\
\text { placed close to the observer as well as perform its } \\
\text { function as the building structure. } \\
\text { - The use of pedestals as forwarding to the foundation } \\
\text { of the column. This reference base with the formation } \\
\text { of pedestals on the old Javanese buildings, although } \\
\text { with a different solution. } \\
\text { - Use of system structure on the veranda manjing art } \\
\text { gallery supporting the roof of the hall. } \\
\text { - Use petangan on the roof rafters. In the main building } \\
\text { using kitri count is a count of two each multiple of } \\
\text { five. While in the building supporting the use of roof } \\
\text { rafters village using appropriate calculation count } \\
\text { POP, which is the count of three each multiple of five. }\end{array}$ \\
\hline & & Space & $\begin{array}{l}\text { - The division of space by keblat papat pancer limo } \\
\text { that divides the site into four parts and the intersection } \\
\text { of the center line or pancer. } \\
\text { - zoning of space where the center becomes more } \\
\text { precious than the marginal (edge / outside). } \\
\text { - Distribution of levels of vertical space in which the } \\
\text { upper is more noble than the bottom. } \\
\text { - Hall as a place of public activity in the TVC Java } \\
\text { became the main gathering place or plaza in the } \\
\text { middle. }\end{array}$ \\
\hline
\end{tabular}




\begin{tabular}{|c|c|c|c|}
\hline No. & Phase & Parameter & Design Concept \\
\hline & & & $\begin{array}{l}\text { - Circulation of the main issues in the museum using } \\
\text { the interpreted position of the movement of the market } \\
\text { based on past days in the Java community is a market } \\
\text { where conventional public space at the time. } \\
\text { - Gallery can be translated as a storage and can be } \\
\text { placed on top of that also means no contact with the } \\
\text { ground floor. } \\
\text { - Outdoor activities are placed under crowded and not } \\
\text { limited by walls, because the architecture of Java, man } \\
\text { was just temporally dropped in, not stopping in. } \\
\text { - The importance of a movement or circulation flow of } \\
\text { visitors / observers could be adapted from the market } \\
\text { movement as a public space past the Java community. } \\
\text { This movement follows the pattern of daily movement } \\
\text { of the market. } \\
\text { - Position in the more noble than those translated } \\
\text { below the starting position at the bottom and gradually } \\
\text { toward the top. The journey from the bottom toward } \\
\text { the top is a symbol of the journey toward better } \\
\text { conditions } \\
\text { - Use of space-facing orientation of the north-south } \\
\text { and divides the site into four large rooms with a single } \\
\text { center. Center can be obtained through meetings } \\
\text { between the diagonal line the corner. } \\
\text { - Java Architecture is a complex of buildings is } \\
\text { generally a lot of mass and the museum also divides } \\
\text { the building into a lot of mass. }\end{array}$ \\
\hline & & Surface & $\begin{array}{l}\text { - Wood materials on the majority of building } \\
\text { components is one of the architectural character of } \\
\text { Java. As one symbol of the closeness to nature the Java } \\
\text { architecture that used wood materials can be used. And } \\
\text { remind the observer of the richness of Indonesian } \\
\text { wood Talah depleted and the need for conservation. By } \\
\text { making use of the wood material into a human- } \\
\text { intensive, so many people are involved and are not } \\
\text { directly participate in the prosperity of this community } \\
\text { is a field worker. } \\
\text { - Java Architecture is a complex of buildings is } \\
\text { generally a lot of mass and the museum also divides } \\
\text { the building into a lot of mass. }\end{array}$ \\
\hline
\end{tabular}




\section{RESULTS AND DISCUSSION}

\section{Determining Function}

The thesis will be discussed proposing a museum program with additional functionality into the site with the goal to be able to bring back the special values of the local site that can positively impact the social, cultural, and economic. Determination of the museum as a proposed new program based on the notion Martono determination criteria relating to the historic building as a museum (Martono, 1975). There are values to be considered to by accessibility values, historical system, community activities

New facilities to the Museum considered to be the solution for the problems. Those main facilities were The Gallery of Struggle, The Art Gallery, The Art workshop, Outdoor Exhibition Gallery, Performance Stage, Plaza, Garden, Prison Wards Style Caffetaria, and Urban Farming Garden.

\section{Spacial Planning}

Refering to the Mancapat, space is divided in four parts of the site Prison right from the middle through the intersection diagonally. Then adjusted to the new access on the north by adding the circulation path of motor vehicles that was connecting Jalan Pirngadi and Jalan Koblen Kidul. Axis formed by the pattern takenfrom both residential and educational facilities around the site. Grid pattern is formed as a reference the initial order of the mass forming at the site. Then the process determines of the central point of the site as "pancer" on the site that became the center of orientation as well as the most sacred point in the site. This process focuses on dividing the site into four parts, according to past behavior of the Java community that divide the space into four sections and one center in the middle of the four.
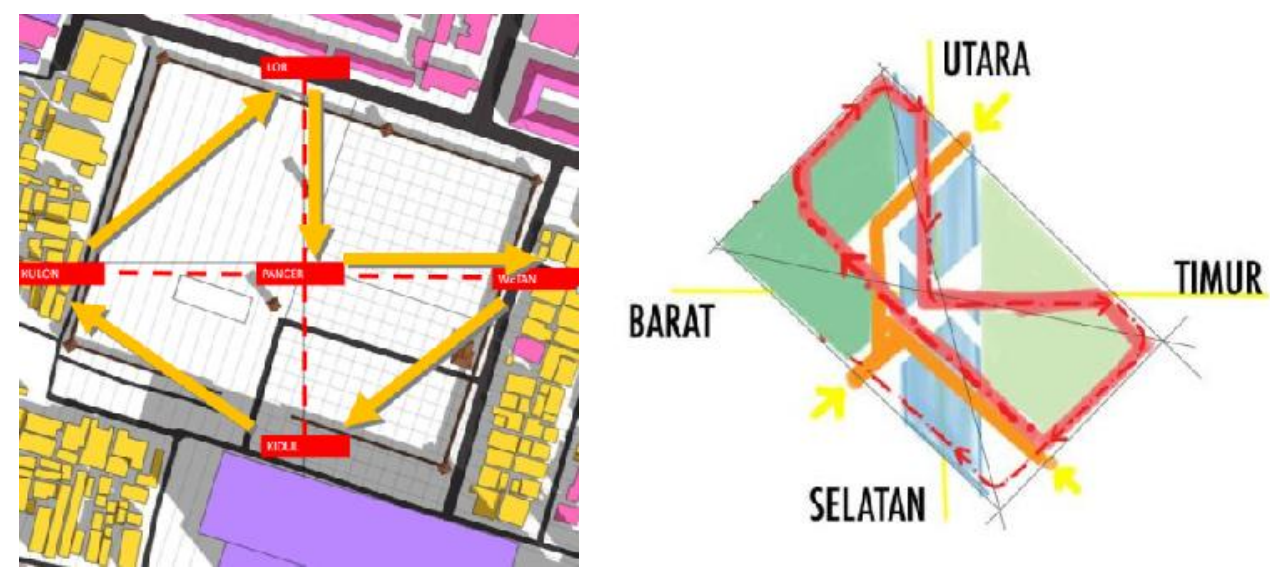

Figure 3. Diagrams of Space Planning and Circulation Arrangements 


\section{Circulation}

Main circulation in museum galleries is an articulation of space based on the movement of public space as well as the past of Javanese class society based on division of vertical zoning and edge-center where the top is more noble than those in the lower and central is more noble than those at the edges. The nobility in this design was determined by the frequency of human activity and the approachment to the future on a space provided. In this approach, the objects of art are considered as objects that have a higher rate than the nobility of the objects in the gallery of struggles that were looking to the past. Objects of art meant to be the nation's ongoing struggle to the future than the objects in the gallery that overlooked the struggle in the past. So that the horizontal (edge-center), art gallery located in the center of the struggle surrounding the site and gallery. Besides that, the approach is also intended to provide a symbol that no existing on the edge (struggle) is the center will never reach its peak. Figure 4 shows a simple movement that is expected from the gallery so that visitors can approach the hierarchy of architectural space in the direction of Java. This approach is not seen directly in observations, but visitors can understand it after they have traveled through the flow path.

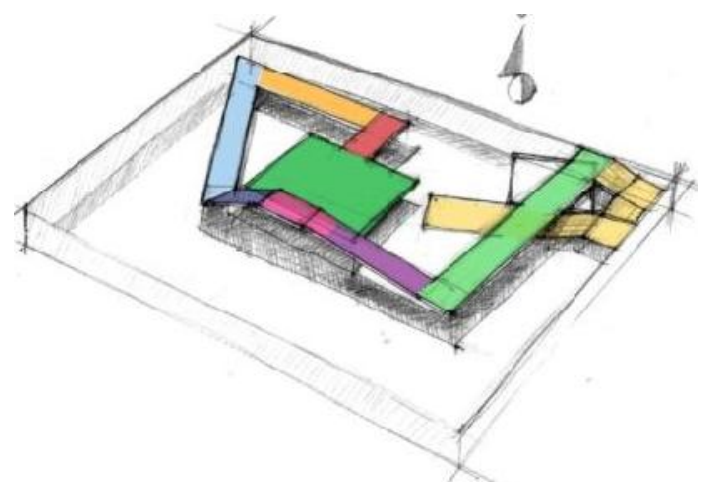

Figure 4. Applied Circulation Diagram of the Museum Gallery

Public space past the Java community who are not on one particular area of public thought in the form of special and diverse market of public activities going on there. Through the metaphorical path to transfer a market position that each day following the orientation pattern of the wind will be generated according to a main circulation path provided for the site. Circulation is one of the important issues relating to penghadiran a museum. With the indirect pemetaforaan then there was a union between architecture and narrative form that is more solid.

After making the formation of the orientation axis in the direction of the wind, followed by determination of the facilities provided on site. In accordance with the hierarchy that can be drawn from the mass distribution of building on Java architecture. Building managers are analogous to griya wingking, ward food as pawon. 

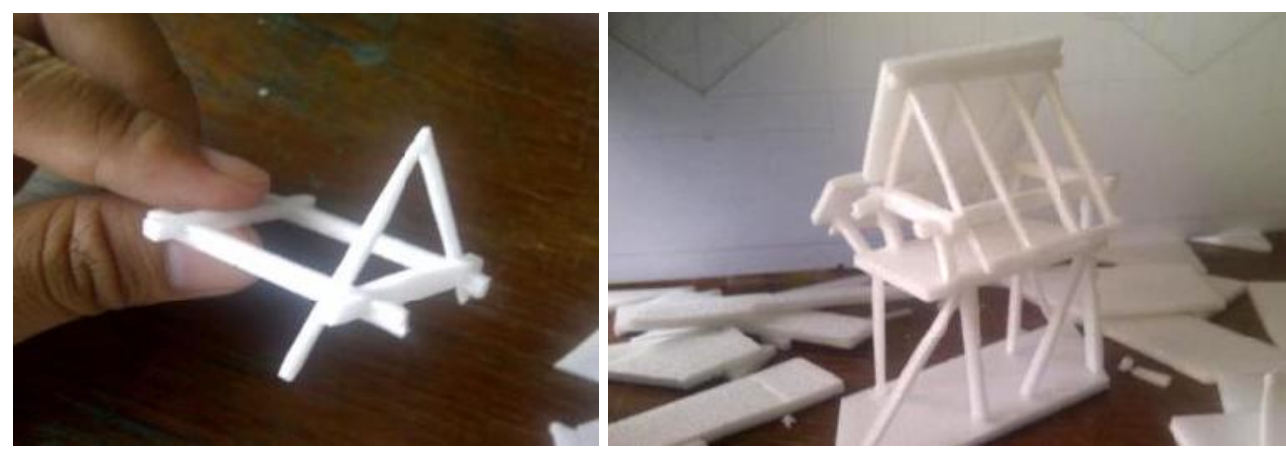

Figure 5. Models of the Gallery Modul

Basic component of Java architecture in the translation chapter consists of three major components, namely guru (includes blandar and pengeret), empyak, and balungan. The composition of those three was also a vertical sequence in which empyak, which is the top position, connected to the balungan through the middle by the guru. Guru considered to be the beginning of the formation of Javanese architecture framework so that the presence of the other components appeared after guru's form was determined. The simplest for of the guru is blandar and pengeret that combined by manjing (united together).

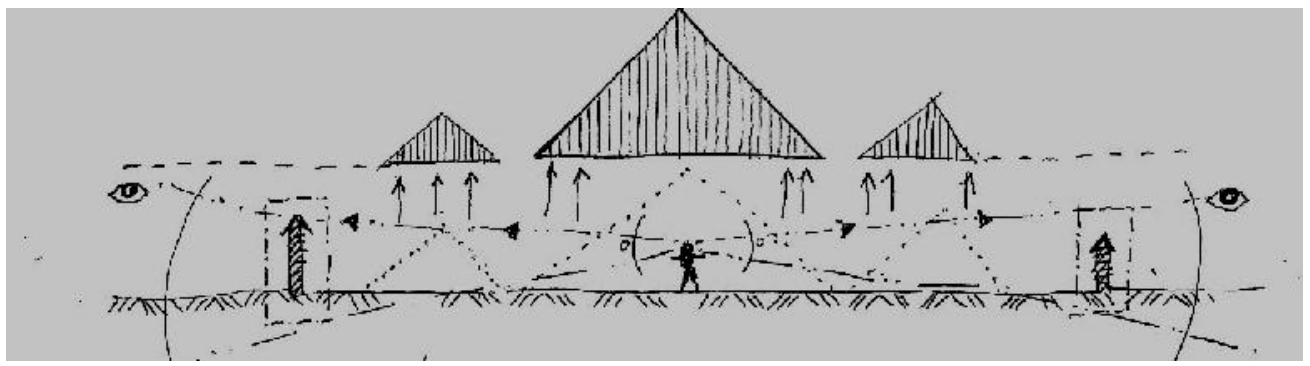

Figure 6. Sketch of Mass Construction Purposes Lifted from the Ground

Mass that dominates the design is the interpreting of the three components that determined by a square formed by the orientation axis based on the area that was created earlier. Almost the entire mass of the building lifted off the ground with the main objective to keep visitors coming to see the original protective wall built by the Dutch, as in Figure 6. It allows visitors who are in the middle were able to experience in a large prison complex.

Similarly, the raised mass for the gallery as an approach analogous to the architecture in the Java community as a large tree for a while underneath sheltering from hot sun and pouring rain, as in Figure 5. Above postion was an analogy approach of that argumentation and space beneath it as part of the public space. 


\section{Phase 1 (Isolated/Colonized/The Dutch Colonial Architecture)}
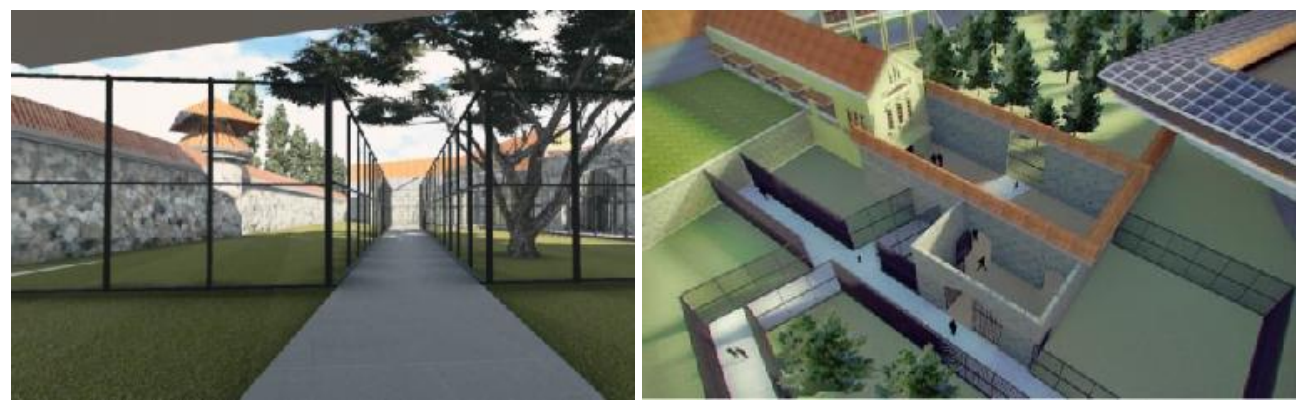

Figure 7. First Gate of the Gallery of Struggle for Indepence (Left); Reception Area before Entering the Gallery (Right)

The entrance gallery of the struggle that was on the north side (Figure 7), started traveling with the show's main asset, namely land Koblen prison walls of the original fence. As an application of the concept of stages of 'alienation', green land stretching limits given in the form of a high wire fence that can not be entered. Visitors will see immediately following the prison wall with a tower supervisor first. The access into this struggle Gallery alienate visitors who enter the presence of additional wall material similar to the character of the prison compound wall of the original Koblen built with limestone.

In some parts made openings that allow visitors to see another part of the wider museum and have more activities, such as plazas and parks. These openings can also see the position of the control tower is still standing so while maintaining the consistency of 'alienation' at this stage. Before actually entering the gallery space in the struggle, the visitor enters the room, surrounded by high walls transition made from high limestone with a surface of sand at the base of the room, as in Figure 7. This effort was intended to bring further isolation approach, with the addition of steel latticed openings that allow visitors to watch the other guests in the green parks and plazas are more widely and freely, as in Figure 8.

Dutch colonial buildings with characteristics signifies the beginning of the journey in accordance with the conclusion of visitors who used the story of the Dutch colonial architecture, colonized, and Isolated. The design method was typological and Unification with reference to the original building and the character of the Dutch colonial architecture of the building. 


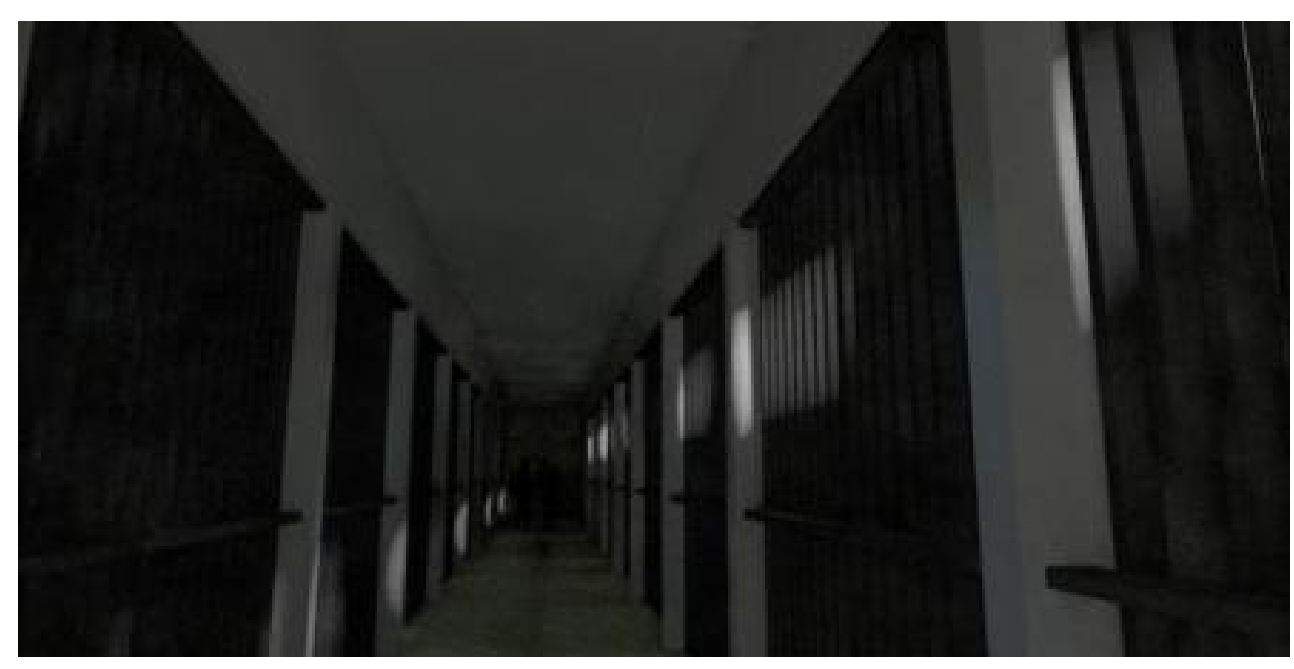

Figure 8. Prison Cell Hall Inside the First Phase of Gallery of Struggle

Figure 8 shows the approach to the design stage of isolation in space. Visitors are given a room with barred cells obtained entered the narrow hallway, dark and elongated. Lighting and sound from the outside can still be entered, although in very small amounts. Trellis and the cells will lead to one again next trellis left open and will take visitors to enter the stage of 'Disorientation' in the next phase.

\section{Phase 2 (Disoriented/Colonized/The Dutch Colonial Architecture)}

Labyrinth is an iconic approach taken in the design phase of 'disorientation' this. Street and alley similarity of branching causes the viewer to get lost and feel the real oriented conditions. Tunnel found in this labyrinth can be seen in Figure 9.
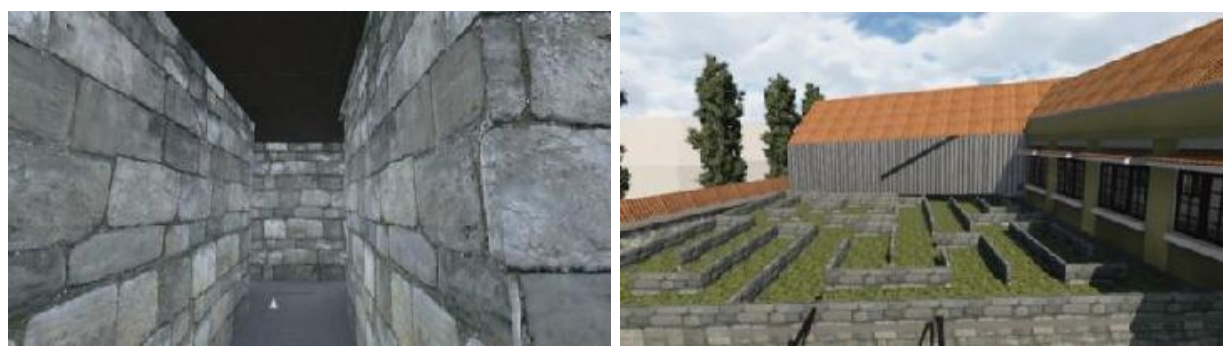

Figure 9. The Labyrinth and Cover on Top of the Labyrinth

In Figure 9, the upper surface covered with vegetation room labyrinth of life that has a surface which is a labyrinth floor plan that has been passed on by visitors to the previous room. Labyrinth can only be seen from above as an expression of enlightenment and realized where the stage can be seen from a different point of view of the conditions that have been passed in the past. This pattern is certainly easier to solve than the solution must be passed directly on it. 


\section{Phase III ('collapsed')}

Design approach used is generally dominated by the junction expression and delineation of clear separation between the old and new parts. In the figure 10, a direct meeting between the newly created mass of the building is very different from the use of metal materials and geometrical shapes different from the compound wall. The use of metal material as seen in Figure 10 is also a symbolic approach to the stage where the show slumped darkness with a metal material with a minimum aperture shaped incision lines. In this section, visitors can feel the immediate walls of the prison fence in a gallery space that is close to the experience of heritage buildings.

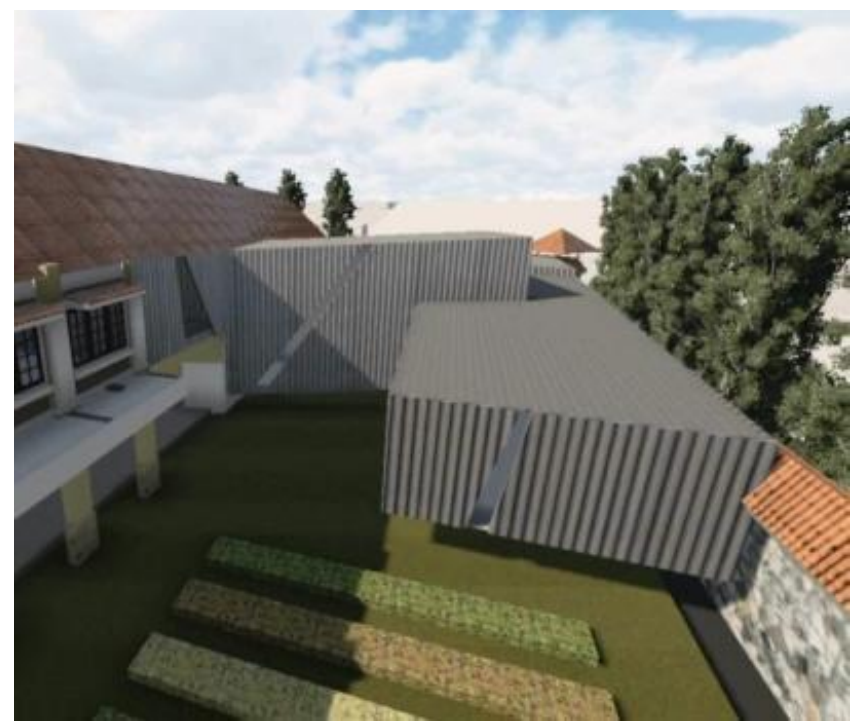

Figure 10. The Meeting Between the Characteristic Mass in the 'Collapsed' and Colonial Character

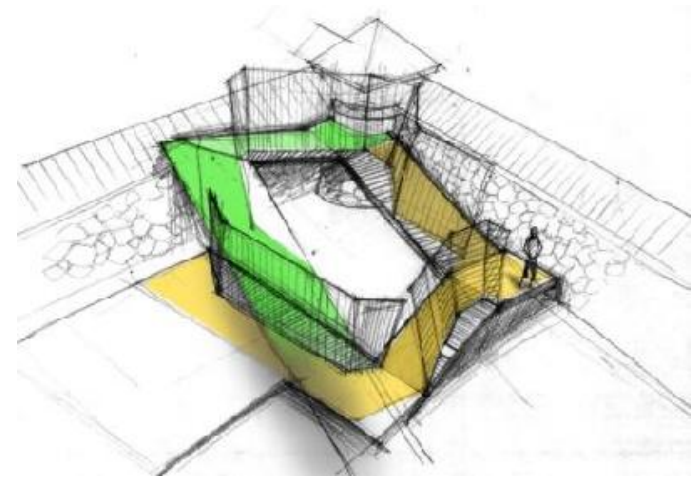

Figure 11. Diagram of the Pattern Space in which Visitors Pass in the 'Collapsed' 
Preparations are expected in the concept of space is narrow and dark places, have a little lighting, and climbed to the top of the burdensome trip visitors. Figure 11 shows transparent view of the room passed by the visitors at this stage to the next stage above. Starting from the opening stage of disorientation in the previous stage to meet the wall of the prison fence Koblen (yellow) to the top line (green). Surface in both the walls and ceiling of its irregular surface is narrow in some sections and slightly wider at the other. Figure 11 shows a sketch pieces of the stage of 'collapsed' to coincide with the wall fences Koblen Prison. This trip was to bring visitors to the different atmosphere with direct touch with the original compound wall and minimal lighting the narrow room.

\section{Phase 4 (Realized/Enlightened)}

Assembly sector teachers, as shown in Figure 12, and the system connects the empyak linking structure and foundation beneath the structure. Sector is the teacher who is forming the space that could be used for a gallery exhibition and collection of information. Virtues and sleigh beam is shown to the observers that its position is brought closer to the height of the observer. Beam and the sledge is made of wood materials in general architecture of Java. Its use in the design to be created is expected to meet structural requirements as well as a symbol for the Java architecture. So that the material to be used on a single piece of wood is a material commonly used in the past the Java community.

Having determined the form of assembled frame that will be forming chamber through a series of beam-sledge, it can be explored through architectural models with a small scale, as shown in Figure 5. The images also show that a rafter supporting the roof surface. This model is made of sheets of styrofoam (polyurethane), white cut line with a reduced size.

In the sector of guru, assemblies adopted manjingan (physically interconnected) which is used in the Java architecture. The hope is to communicate the icons and symbols of Java, as well as an index for the reinforcement of the roof structure. Once finished and then assembled balungan empyak other components. Part of the framework that is in contact with the foundation made such random according to an analogous approach to the trunks of trees that are not uniform and also a symbol of the beginning of the 'nation's bersatu' the' story 'freedom struggle'. This approach can be seen in Figure 11 shows a surface layer of the roof that complements the gallery empyak components. This layer serves to shelter visitors in the gallery upstairs as well as those in the shade beneath the floor.

There are two alternative column called for connecting balungan to the top of the foundation. The first is arranged at random and the second is that has been in regular conditions. This regular column canonical design process which has worked over so it is not straight up but it is divided into two and has a tilt angle for wanting to 
continue the approach of previous columns are analogous to the trunks of trees which are rarely straight. Visualization approach can be seen in Figure 12.

As a symbol of the architecture of Java on any balungan a meeting with the foundation found pedestals. Although these pedestals has a function as the foundation on Java Griya but because it needs a large load is transmitted again extolled the pile foundation is not visible in the soil. Adaptation to form pedestals can be seen in Figure 12. The meeting between balungan with these pedestals are not bound by rigid joints such as the architecture of Java in the past, although with different materials.

This gallery does not have the room typology wall components, so overall just a roof, the room in the roof and the existing open space underneath. This approach is related to the architecture of Java and the archipelago are basically familiar with the wall. This design approach was intended to give an idea that inanimate objects (object collection) placed above and more human activity that is not shrouded beneath and just shaded.

Because of this struggle Gallery is located in the center as one of the most venerable roof is formed by taking the typological approach to the design of dhapur village. In the process takes the canonical and the typological approach in which the original form to be processed back to the geometric reference. As shown in Figure 12 are the first two layers of roof above the eyes of visitors and the second is next to the visitor. Aiming for visitors closer to the Java architecture that is more dominant on the roof processed.

Great lighting needs to be completed inside the building by providing an opening in the top (peak / peak) roof and covered with tempered glass material that has been coated with heat insulation coating. However, because the amount of energy that comes the sun at noon in the equatorial region is not good for the collection and visitors then mounted reflector and insulator again just below the glass, as can be seen in Figure 12. So light that illuminate the reflection of some of the surface. To support the scene and the lighting made other openings in the roof which also features two shading (sosoran), as shown in Figure 12.

Then processed forms that have been made which will serve as modules that can be used over and over so that the resulting space can be elongated like the concept that has been decided in the previous chapter. This approach can be seen in Figure 12 which also shows the fractional components forming the gallery. 


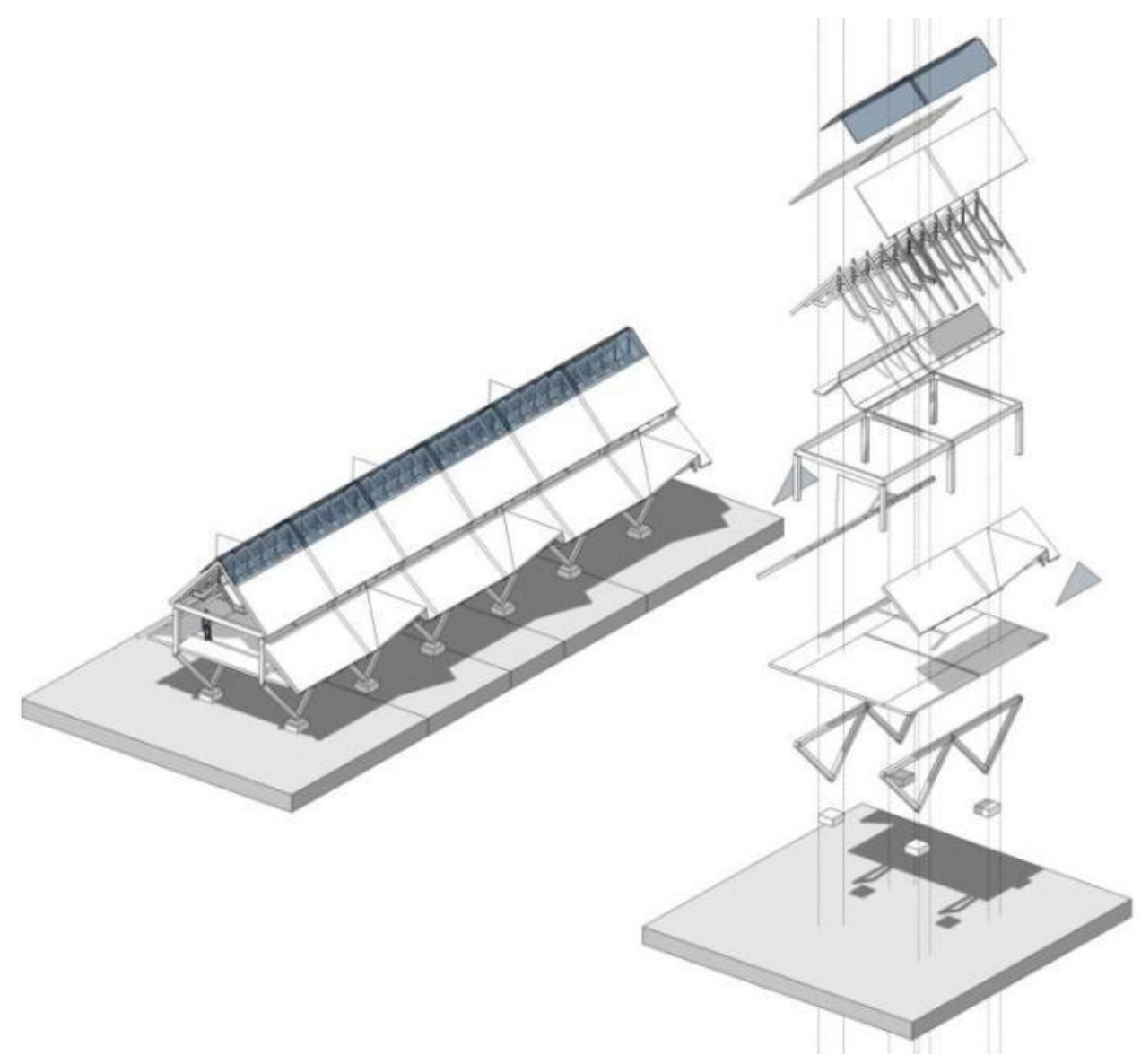

Figure 12. Model Galleries that Have been Adjusted Scale and Size

The story of the journey narrative of 'development architecture' can be obtained by transforming architectural style of the Dutch colonial architecture to the Java Architecture over time in the gallery module that had been developed earlier. Over time the analogy here is the start of the journey from the entrance gallery to the peak of the main art gallery. The initial approach of Dutch colonial architecture is described as having a left end the dominance of the massive lump of concrete and brick material and have a little shade on the top of the window width. In the second line, the formation has been used as a walkway around the surrounding air so that the adaptive filter in the air more comfortable. Similarly, the lighting is in the middle of this has been covered through a corridor that does not directly go into space because of the amount of activity in the energy of sunlight in the region around the equator. And lastly, the right end of the described architecture developed by taking into account the re-architecture of Java. This approach is not the imitation of Javanese architecture found in Java Griya that ever existed in the past but rather results from processing architecture based on the principles of Java. 


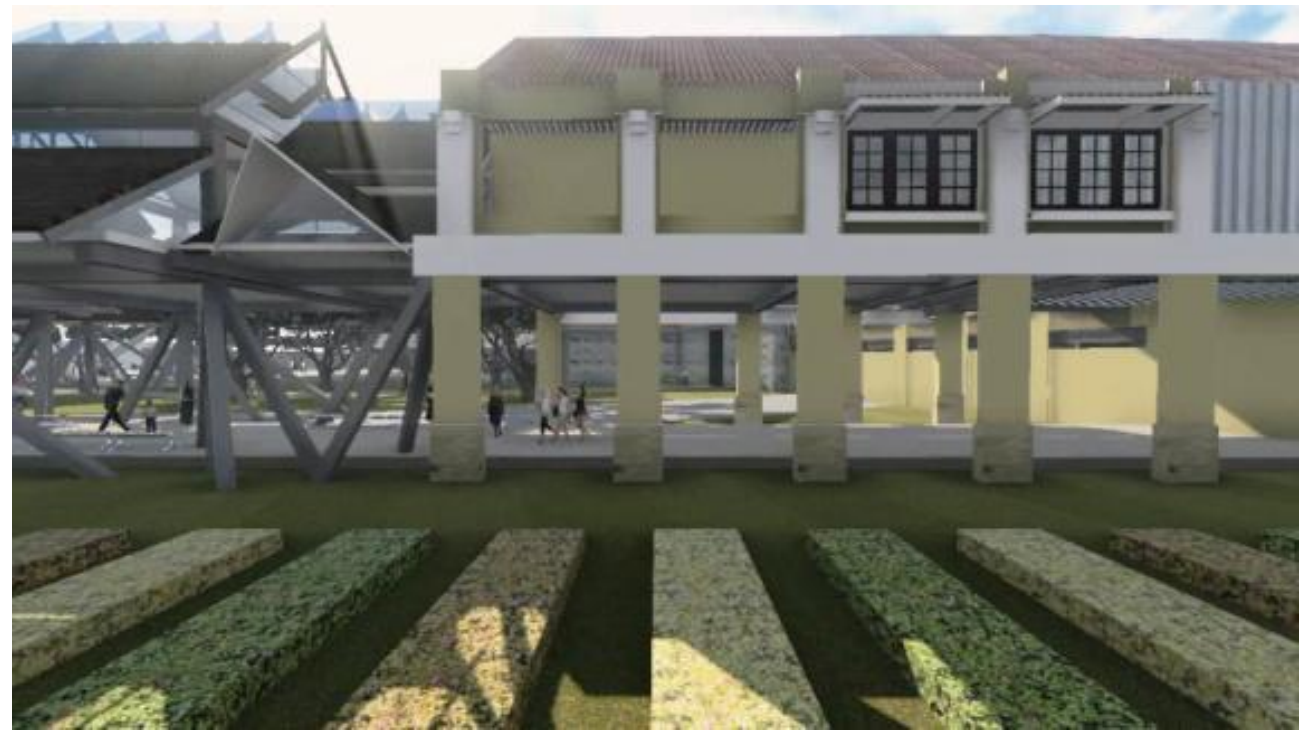

Figure 13. Transitional Character of Dutch Colonial Architecture Switched to the Java Architecture

Picture 13 shows the transition between the Dutch colonial architecture approach that gradually turned into a Java architecture (left). The use of wood materials in the architecture of Java is quite a contrast to the use of concrete and masonry materials in the previous stage. Picture 13 shows the columns are still random as a new expression of conscious nation to unite. The bottom of the shaded gallery can be used by visitors to just meet or sit. The bottom of this space is a public area that is free to use the community.

Inside of this mass is a general picture gallery space featuring the struggle and the collection of information relating to the Surabaya people's struggle for independence. This space is to use a neutral surface is light gray color with a few openings. There is a concrete beam-sledge of the real which is not far from the eyes of visitors. Opening of this phase, as shown in figure 13 can view the farm atmosphere that can be seen from the viewpoint of occupation cultivation, although activity is the actual activities of the community surrounding the prison wall background.

\section{Phase 5 (In Battle - Independence - Defending)}

On one of the telling of the struggle Kemerdekaraan 'Fighting', carried out a literal interpretation of the actual bombing. To get the proper help of computer simulations are used, namely the production application is Autodesk 3D Studio Max. At the gallery corridor that is intended in this phase is modeled in 3 dimensions digitally and then incorporated in the software simulation of the above. This scene uses a point source of explosion by a few frames at the two points, namely the explosion 
that allegedly occurred at the new entrance (north side) is also as an alternative access opening.

A standard explosion resulting from a point source, performed in one stage part of the Gallery of Struggle (phase 5) so as to produce a sequence of blasting process. The moving process is then recorded per frame and then choose which best suits your needs. Finally the choice fell on the frame to 17 at a speed of 30 frames per second, as in Figure 14.
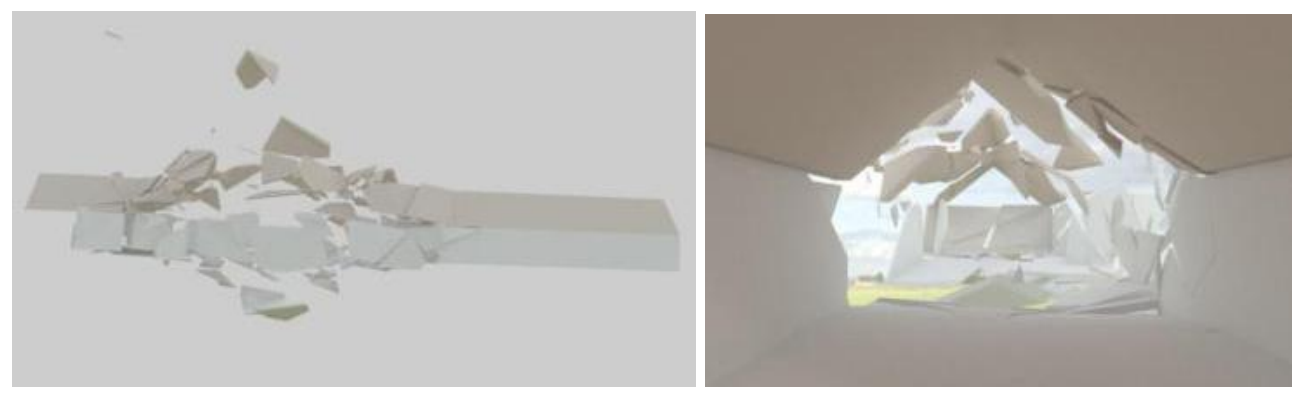

Figure 14. Simulation of Exploding Gallery Part Caused by a Single Bomb Using Computer Simulation

The use of structural steel tubes as the support of fractional parts of a building at the Gallery struggle can be seen in Figure 15. Structures that support the visitor's paths here was using arch-shaped bridge system upon which relate to the main structure of the system at both ends.

The middle part tells the 'independence' are at the highest position of the curved bridge is where the veil is the most open and direct contact with outer space. This position allows visitors to view the scenery outside and also have an alternative road to go down and into the Show Room Lobby. This meant the freedom of a person as an independent. This position is also directly refer to the position which is free from the sheath and could immediately feel the blast of air, light from the outside, and rain water when it rains. Circulation to the position under the tower is connected by a supervisor be reconstructed. This picture can be seen in Figure15.
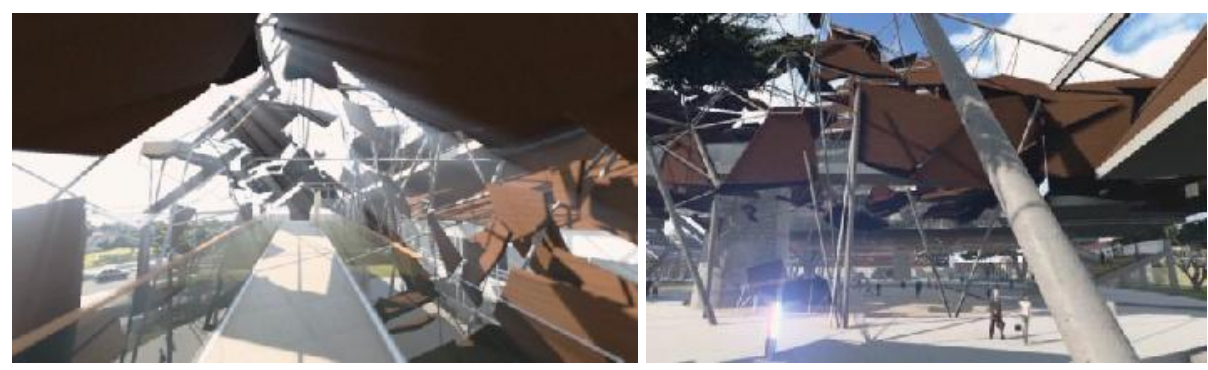

Figure 15. The Broken Parts and Steel Pipes Connected to the Structure 
Figure 15 shows the fraction of the wooden surface is supported by structural steel tubing. There is a meeting with the reconstruction of the bridge is the old tower that uses metal material as a liaison with the lower chamber. So the relationship with the ladder on the tower allows visitors to go up or down to the pavilion in the plaza below.

The old control tower that has been damaged in the south to be rebuilt, but only its form it is used as reference. The shape is cylindrical with a fixed geometry of the upper end is smaller than the cross section below. Material and its function changed to adjust the current conditions. The tower has a function connected with the circulation of the ground floor room at the top. Constituent materials using a porous metal material (pervorated metal cladding) with a steel frame as the main structure.
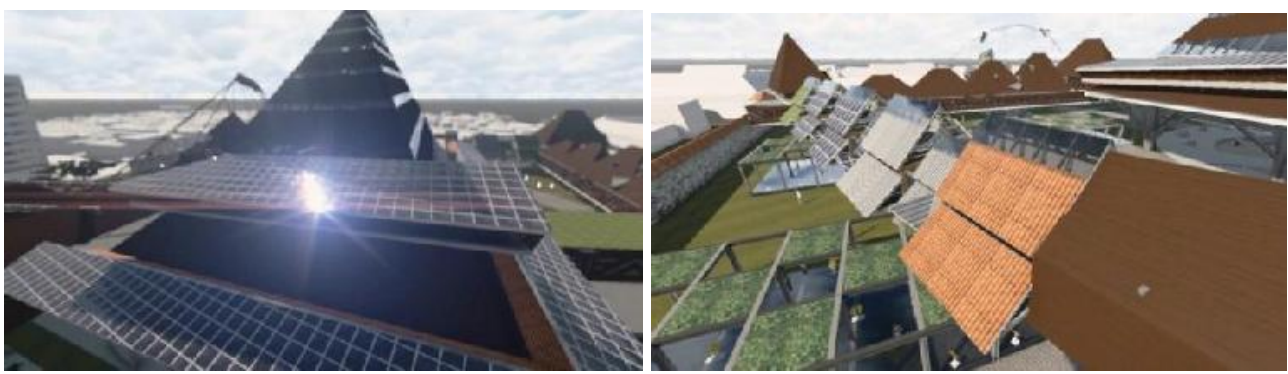

Figure 16. Phase 'Creating' is Shown from the Outside Through the Roof of the MultiMaterial Experimentation

\section{Phase 6 (Creating)}

Roofing on Selasar Art Gallery is using solar panels as a symbol of innovation on the stage of 'work' so we get a better life by saving energy. Wide field that can be found on the roof of the potential of solar panels to collect energy from sunlight that great outpouring of the city of Surabaya, as shown in Figure 16. The panels are mounted around the walkways surrounding the opera house in the middle of this.

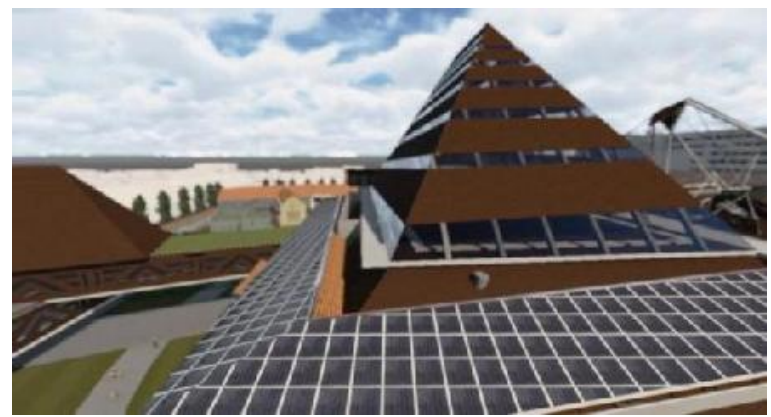

Figure 17. Use of Petungan, Empyak Constituting the Rafters for Major Art Galleries from the South 

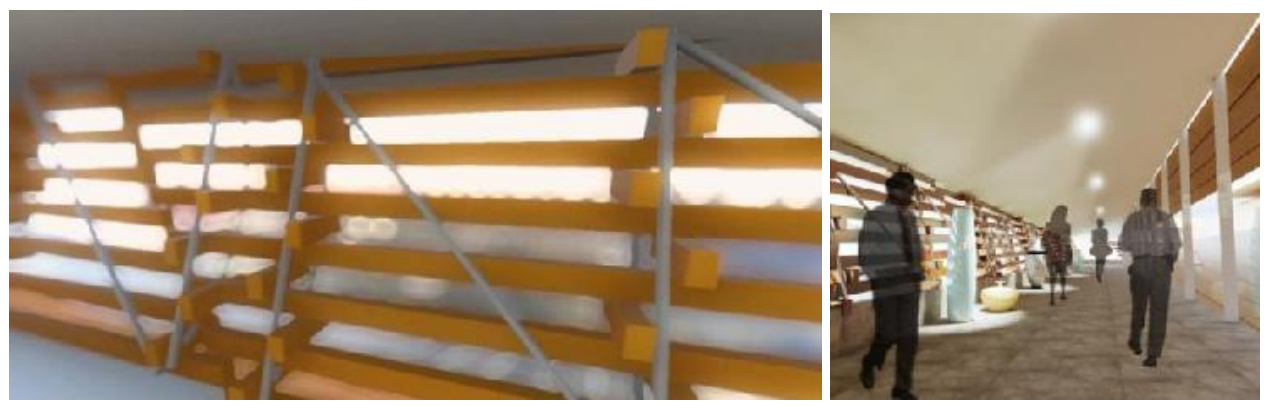

Figure 18. Interior View of Art Hallway and the Use of Manjingan on the Screen

On the existing temporary art gallery above shows the use of rafters who follow the rules petungan (count Java) for roofing. Usage count of the number of rafters is a symbol directly to the Java community. Although using a different approach than Griya Jawa building in the past, this effort is the communication to visitors about the local architecture. Figure 18 shows the use of wooden roof manjingan sun-screen in the hallway art gallery. Wood that is not getting compiled by bolt directly but only at the end of the meeting with other structural systems only. Small steel rods are used to reduce the deflection that may occur in a wide space. Figure 18 (right) shows the inside of this Selasar Art Gallery. This room provides space to display art collection permanently set in a prison that can be seen from her all the wood cracks.

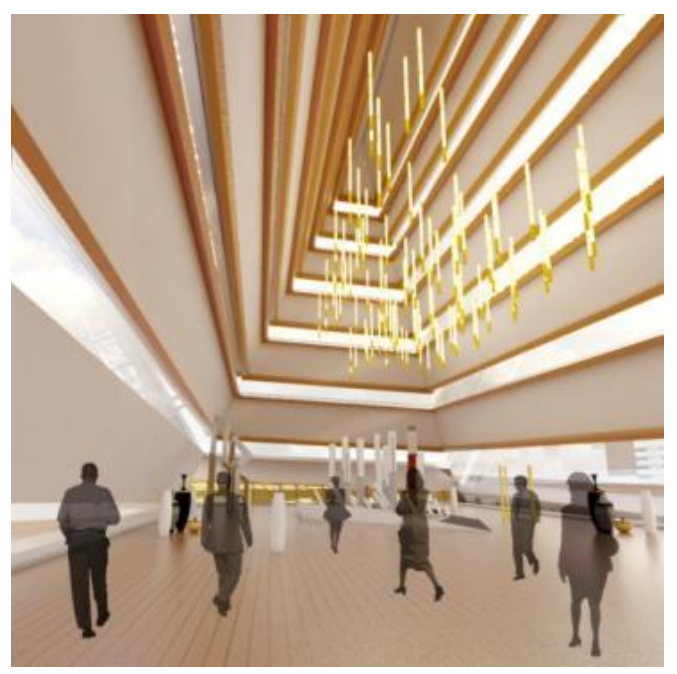

Figure 19. Interior View of Main Art Gallery

Temporary Art Gallery is a vehicle for a thematic exhibition of art works and does not last long, which can be seen in Figure 19. It can be an art exhibition installations that require large space and other art items. Openings around which pretty much gives a view of some prison as well as the wider city of Surabaya. Surface of the 
roof needed to heat insulation and two layers of glass in the middle empty. Although such activities are no longer (temporarily) a program in this room, so that the artwork on display do not linger in this room very bright.

\section{CONCLUSIONS}

Architecture as a medium of communication which can occur in a system of signs which were introduced in the model of Charles Sanders Pierce's triadics. Triadic model has three main components that allow the interpretation of an architectural object, the message the designer, building and construction observer. Components are most easily controlled by the designer and the designer is the message of the building, while the observer is an uncontrolled variable, but may actually be directed. This approach can be adapted to 'the contents' component to be conveyed and 'expressions' used in which each represent a designer's message and the building itself.

Excess of the draft Prison Museum Koblen both design methods and results are realized this is its proximity to the stories the background of a cultural heritage site. As a museum that provides information and knowledge relating to Indonesia's struggle for independence, Prison Museum Koblen as architecture and the built environment create a background that supports the telling apart of the collection, information, and program activities that occur in it. So with the realization of the story to be conveyed in the form of architecture, museums aim to provide the knowledge, appreciation as well recreation may be more optimal.

Koblen Prison Museum that uses this approach to historical interpretation of the story has the distinction of other precedents that have been discussed previously. Design approach that uses the history of exploitation of this advance the story raises are not just one. Various events have occurred over time at a site. Gathering evidence to bring the story of the history of the story, so diverse, there are various different perceptions of history here. This approach is already complex enough to be complexity in architectural design.

Complexity of the story will be presented more easily and systematically when assessed based on the signs that appear are the semiotics. So this approach compared with other approaches to the precedent that has the breadth of meaning are obtained through the translation of the sign. Nevertheless the results are not necessarily become redundant because the criteria are made based on the signs that have been simplified.

Use of methods based on the model triadik Peirce makes it possible to provide a more comprehensive picture of the relationship between architecture raised signs with the intent of being understood by visitors. Although it does not rule out the possibility of meaning that extends for all signs used do not refer to an object 
directly, the role of museums with diverse collections and information can be complementary as well as narrowing the meaning.

Museum which is built on the heritage environment sometimes we do not have the integration of cultural values contained in it like a story or history within the scope of the architecture. The approach taken in this thesis are expected to relate these values to architecture. Diverse business needs to be done to better integrate a design for the environment, region, and the communities where the cultural heritage. Peirce's approach mewacanakan something can be understood in its meaning based on signs that can be raised. So this approach will indeed be significantly different from each observer based on a different background. However, using the marking was too literal at times will bring up the boredom and the impression is not creative.

Apart from this approach as a whole without regard to the meaning of behavior that arise from the presence of narrative expression. Magnitude of the effect of architectural expression of the observer in the form of the kepahamannya to present the stories of cultural heritage sites worthy of further investigation. Recovery of cultural heritage denied land, especially Koblen Prison, have also investigated the effect of this site into a museum when compared with other functions such as shopping centers, or family recreation arena. Other functions are more efficient and more positive value needs to be done further research. This activity also has relationship with the study of the program and the study of the feasibility.

Java architecture that does not directly appear in the design that made this thesis gained new opportunities to be explored. Java, it can be integrated architecture design approach or the other interpretation, which would certainly enrich the knowledge of the architecture of the archipelago.

\section{REFERENCES}

Broadbent, Geoffrey (1980), The Deep Structures of Architecture in Broadbent, Geoffrey, Bunt, Richard. dan Llorens, T, Sign, Symbols, and Architecture, John Wiley \& Sons, New York.

Dougherty, Bruce Travis (1990), Architecture as Communication: An Application of Semeiotic to Meaning in Architecture, Thesis, Master of Architecture, Graduate Faculty of Texas Tech University, Texas.

Jenks, Charles (1980), The Architectural Sign in Sign, Symbol, and Architeccture, eds. Broadbent, G., Bunt, R. dan Llorens, T, John Wiley \& Sons Ltd. New York.

Noth, I. (1990), Peirce in Handbook of Semiotics, Indiana University Press, Indianapolis, hal. 39-47.

Surabaya City Goverment (2003), Rencana Tata Ruang Kota, Dinas Cipta Karya dan Tata Ruang Pemerintah Kota Surabaya, Surabaya. 